\title{
O FILÓSOFO ESPINOSISTA PRECISA CRIAR VALORES? ${ }^{1}$
}

\author{
Homero SANTIAGO ${ }^{2}$
}

- RESUMO: Tanto Espinosa quanto Nietzsche promoveram uma análise crítica da moral vigente; ambos terminam por descobrir a falsidade da concepção de valores transcendentes. No caso específico de Nietzsche, tal operação o conduz a determinar a criação de valores como uma tarefa imperativa aos novos filósofos. O mesmo poderia ser dito de Espinosa? Não encontraríamos no espinosismo algo que se aproximasse de uma necessidade de criar valores? Buscamos responder a tais questões mediante uma análise do início do Tratado da emenda do intelecto.

- PALAVRAS-CHAVE: Espinosa, Nietzsche, valores, moralidade, bem e mal.

Para o Luciano.

\section{I}

Nietzsche, como se sabe, em certo momento da vida chegou a ver Espinosa como um precursor. Num célebre texto de 30 de julho de 1881, anotado sobre um cartão-postal, ele exclama: "tenho um precursor e que precursor!", dando medida do quanto, àquela altura, não apenas se identificava como fortemente admirava esse pensador holandês que é "o mais fora da norma e o mais solitário" e, por isso mesmo, o "mais próximo" de si (Nietzsche, 1986). Ainda que a partir de então vários outros textos e passagens

\footnotetext{
1 Uma versão inicial deste texto foi apresentada no I Congresso internacional Spinoza e Nietzsche, UFRJ-Maison de France, Rio de Janeiro, junho de 2006.

2 Professor Assistente Doutor do Departamento de Filosofia e do Programa de Pós-Graduação em Filosofia da Universidade de São Paulo-Usp. Artigo recebido em mar/07 e aprovado para publicação em jun/07.
} 
nietzschianas venham a criticar Espinosa, ${ }^{3}$ a despeito das diferenças entre uma e outra filosofia, são de fato inegáveis alguns pontos de grande proximidade; o próprio filósofo alemão arrola alguns em que a convergência é patente: fazer do conhecimento o mais potente dos afetos, negar o livre-arbítrio, negar a teleologia e as causas finais, negar a ordem moral do mundo, negar o mal. ${ }^{4}$

Seguindo nessa direção, pressupondo essas semelhanças no trabalho crítico, nosso propósito aqui é sugerir uma outra congruência entre Espinosa e Nietzsche no que se refere a um tópico específico que é a tarefa de criar valores. É um tema por excelência nietzschiano, evidentemente, e Espinosa está longe de formular qualquer coisa do gênero; pensamos no entanto ser possível estabelecer certo paralelismo entre algumas das exigências e expectativas que conduzem Nietzsche a determinar a criação dos valores como uma tarefa própria do filósofo do futuro e alguns passos da filosofia espinosana; congruência que se dá menos no nível das teses que no proceder, no tipo de resposta a certas questões. Para tanto, cumpre advertir desde logo, teremos de iniciar já um pouco além no rol nietzschiano de encontros, acrescentando especialmente que Espinosa nega não apenas o mal, mas igualmente nega o bem. Por ora, limitamo-nos a invocar as belas análises de Deleuze (1968, p.233; 2002, p.28) que, com razão, põe Espinosa "para além do Bem e do Mal". Esta situação do espinosismo é de suma importância, uma vez que é do completo esvaziamento dos valores que surgirá, também nesse sistema, cremos, o problema de criar valores.

Nosso percurso constará, basicamente, de dois momentos. Primeiramente, uma retomada muito esquemática do lugar da criação dos valores em Nietzsche e a posição dessa questão em Espinosa (quando, esperamos, deverá ficar claro o sentido da pergunta que intitula este texto). Em seguida, proporemos uma análise, num texto particular de Espinosa, do que se pode entender como criação de valores.

\section{II}

A morte de Deus, para Nietzsche, é "o maior dos acontecimentos" de sua época; prenúncio da iminência de uma "longa e abundante seqüência

3 Para uma consideração do conjunto dos textos de Nietzsche sobre Espinosa, pode-se consultar Liveri (2003).

4 "Sua tendência geral", afirma Nietzsche (1986), é "idêntica à minha - fazer do conhecimento o afeto mais potente - em cinco pontos capitais de sua doutrina eu me reencontro, este pensador, o mais fora da norma e o mais solitário, me é justamente o mais próximo: ele nega o livre-arbítrio -; os fins -; a ordem moral do mundo -; o não-egoísmo -; o mal -; se certamente também as diferenças são enormes, isso se deve mais à diversidade de época, de cultura, de ciência." 
de ruptura, declínio, destruição, cataclismo, [...] tal como provavelmente jamais houve na Terra" (Nietzsche, 2001, §343). Pudera! Com o óbito da divindade é o sustentáculo de uma civilização que vem abaixo ou ao menos é posto sob aguda suspeita; e daí a ascensão do niilismo, fenômeno contemporâneo à morte de Deus.

Niilismo: falta o fim; falta a resposta para o "Por quê". O que significa nilismo? - que os valores supremos se desvalorizam. (Nietzsche, 2005b, frag. 9[35]; 1887, p.238; trad.modificada).

A equação explica-se com relativa facilidade. Deus sempre foi o garante de nossos valores, de nossa moral; desde que o bom senhor se retira de cena, tais valores, tal moral balançam, caducam, e terminam por ficar desacreditados. Com isso, desaparecem do horizonte ou entram para o rol das fabulações todas as velhas certezas que serviam para tranqüilizar a existência, particularmente os fins e objetivos, os porquês.

Haverá, porém, duas formas de encarar esse niilismo, e portanto a morte de Deus. Uma forma passiva, outra ativa, como explica a seqüência do fragmento póstumo que vem de ser citado. Por um lado, o niilismo pode determinar apenas um "declínio e retrocesso da potência do espírito"; niilismo passivo que não verá mais que a ausência de fins, valores e porquês, e que não irá além; é o niilismo próprio de um espírito "cansado". Todavia, por outro lado, é possível que o niilismo assuma uma forma ativa; nesse caso, será ele o signo da potência aumentada do espírito, um "sinal de força"; o espírito livre não ficará a lamentar a morte dos fins e valores, pelo contrário perceberá que não estavam mesmo à sua altura (ibidem). Para o filósofo e o espírito livre, a morte de Deus e o nilismo podem tomar a forma de uma verdadeira iluminação, uma "nova aurora"; não que se possa aí estacionar, mas é que o horizonte "aparece novamente livre" e se pode zarpar para novas e perigosas viagens - com efeito, "nunca houve tanto 'mar aberto'" (Nietzsche, 2001, §343).

Tal panorama configurado pela morte de Deus e o niilismo é determinante para o filosofar nietzschiano. Não se passa incólume por tal evento, que vai estabelecer um novo tipo de trabalho, novas questões, novas exigências e, não menos, novas perspectivas. Quais? Podemos arrolar como das mais importantes tarefas determinadas ao filósofo que acata a orientação do tempo (Deus está morto) o cumprimento de uma exigência - a crítica dos valores - e com isso a abertura de uma perspectiva - a criação de novos valores. Convergência, no filósofo, de um passado e de um futuro, um olhar para trás e um vislumbrar para frente; a grandeza do filósofo será justamente saber funcionar (emprestemos uma imagem do prólogo do Zaratustra, §4) à guisa de "ponte" entre os tempos. 
"Necessitamos de uma crítica dos valores morais", dirá a Genealogia da moral (prólogo, §6) Esta necessidade e o empenho em dar conta da tarefa é uma das marcas maiores da filosofia nietzschiana. Como o filósofo vai nos explicar, "à primeira vista", tal questão "parece ser algo isolado"; talvez se pudesse até criticar os valores, denunciá-los, tematizá-los, sem a partir daí abrir imensas perspectivas. Porém, aos olhos de Nietzsche já não se trata apenas de desconfiança, suspeita, com relação aos valores; tudo isso "cambaleia a crença na moral", mas é preciso ir além. Há uma "nova exigência", apregoa a Genealogia, em que a crítica será menos condenação do que compreensão; é nos meandros desse esforço compreensivo que surgirá o ineditismo do empreendimento. "Necessitamos de uma crítica dos valores morais", já dissemos citando a Genealogia; agora completemos: "o próprio valor desses valores deverá ser colocado em questão". Cumpre sublinhar nessa idéia chave, sob a qual está boa parte da novidade que o próprio filósofo se imputa: indagar pelo valor dos valores. O que é um valor? Sabemos todos, mais ou menos, o que é um valor, sabemos que temos valores e qual o papel deles: organizam a vida e o mundo a partir da perspectiva de um determinado ser; o bom e o mau são modos de valorar as coisas segundo uma determinada perspectiva. Sabe-se que o valor tem uma origem, tem uma história, mas que tal história acaba determinando muitas vezes a passagem de um valor, de uma situação precisa, determinada, a um valor dotado de transcendência e acomodado num certo além ou mundo separado. Assim se erguem valores como Bem e Mal, que não vem mais expressar nenhuma perspectiva mas valorar a tudo e a todos, não sendo porém, eles próprios valorados; com efeito, uma das características da instituição de uma moral é o esquecimento do processo de formação dos valores e o surgimento deles como valores desde sempre existentes e para lá de toda determinação humana. Enfim, os valores são peças que organizam e se impõe ao mundo e aos homens; por isso mesmo não se poderia imaginar que eles fossem os produtos desse mundo e desses mesmos homens.

Aí entrará toda a genialidade nietzschiana, sua originalidade, ao pôr a funcionar uma genealogia e investigar quais as condições e circunstâncias do nascimento de um valor, qual seu desenvolvimento, suas modificações, etc. Esse tipo de conhecimento nunca existiu, assevera Nietzsche, mas é dele que necessitamos. Uma arte histórica que tome os valores não como dados, entes naturais ou determinações divinas, mas produtos humanos dotados de uma história. Eis uma das possibilidades imediatamente abertas e exigidas pela emergência do niilismo; a possibilidade de avaliar o valor dos valores. Mas como? Quem fala em avaliação fala em metro avaliador, portanto num valor que valore o objeto em avaliação; desde porém que os próprios valores devem ser avaliados, qual poderá ser o fiel da balança nietzschiana? Os valores são interpretações; não correspondem a coisa alguma 
no mundo, portanto não se podem deixar avaliar pelo metro tradicional do verdadeiro e do falso, pelo contrário, verdadeiro e falso são também eles valores e para não incorrer em petição de princípio o genealogista deve abrir mão dessa medida fácil. A novidade de seu exercício exigirá um novo fiel, mais objetivo: numa palavra, a vida. Todos os valores deverão ser avaliados por este valor fundamental, a vida, e julgados conforme favoreçam ou entravem a vida. Na Genealogia, com efeito, Nietzsche descreve assim seu "problema": "sob que condições o homem inventou para si os juízos de valor 'bom' e 'mau'? e que valor têm eles? Obstruíram ou promoveram até agora o crescimento do homem? São indício de miséria, empobrecimento, degeneração da vida? Ou, ao contrário, revela-se neles a plenitude, a força, a vontade da vida, sua coragem, sua certeza, seu futuro?" (Nietzsche, 1998, prólogo, §3). Idéia seminal que uma anotação da mesma época do livro resume nestes termos: "Pelo que se medir objetivamente o valor? Somente pelo quantum de potência intensificada e organizada" (Nietzsche, 1999, v. 13; frag. 11[83], 1887-1888).

Eis que a questão dos valores, a "nova exigência de uma crítica dos valores", remete-nos não só ao passado mas também ao futuro. O trabalho histórico, o trabalho crítico de compreensão e avaliação dos valores são "apenas precondições" da tarefa final que se impõe aos filósofos após a morte de Deus; a crítica "requer algo mais", e este "mais" não é senão a exigência de criar valores, noutros termos, ultrapassar o niilismo.

Os autênticos filósofos são comandantes e legisladores: eles dizem "assim deve ser!", eles determinam o para onde? e para quê? do ser humano [...] estendem a mão criadora para o futuro, e tudo que é e foi torna-se para eles um meio, um instrumento, um martelo. (Nietzsche, 1992, §211)

Se os fins e os porquês desapareceram, caberá àquele que ativamente compreende o evento niilista determinar outros - o "para onde", o "para quê"; se os valores se desvalorizaram, cumprirá criar novos valores, moldar um novo mundo servindo-se de todos os meios, de todos os instrumentos à disposição, inventando outros tantos.

Criar valores - mas quais? O metro da vida não pode ser subestimado na resposta. Ele constitui mesmo o fundo de uma resposta que no geral não pode ser senão indeterminada. Não sabemos quais valores se criarão, mas certamente valores, por assim dizer, valorosos a se medirem pelo seu poder de favorecer a vida, organizar e intensificar a potência do vivente. Desde que Deus morreu, os valores são interpretações, criações; então por que não criar novos, talvez até resgatar alguns renovando-os, contanto que favoreçam a vida (organizem e intensifiquem a potência) em vez de entravá-la ou até renegá-la (intensificando a tristeza)? Esses novos valores talvez até ve- 
nham a dar forma a uma nova moral; moral que, como toda outra, seja uma "semiótica dos afetos" (Nietzsche, 1992, §187), mas - ponto capital - que o seja dos afetos alegres, fortificantes de nosso ser; moral que se erga renovada e, particularmente, sem ilusões, ou seja, que não vá buscar lastro e razões além das estrelas, mas que se sacrifique à terra, dizendo sim à vida (cf. Nietzsche, 2005a, prólogo, §4).

Deus morreu?! Nossas certezas balançaram?! Não se poderia tirar dessa morte o júbilo de uma nova existência? Uma nova aurora, a possibilidade de uma nova vida, e uma vida melhor?

É a partir desse quadro sumário, em que buscamos estenografar um movimento propriamente nietzschiano de exigências e perspectivas, que gostaríamos de tratar de Espinosa e, especificamente, da questão da criação de valores no espinosismo.

Tanto Espinosa quanto Nietzsche esforçam-se em uma análise crítica da moral e, em particular, dos valores; ambos terminam por descobrir a falsidade da concepção de valores transcendentes e, portanto, determinar a inexistência do que se poderia dizer uma ordem moral do mundo; por esta via, enfim, ambos aportam numa situação de "niilismo", quer dizer, o resultado de suas análises críticas nos instalam num mundo em que os valores tradicionais se desvalorizaram. No caso específico de Espinosa, tal afirmação decerto exige explicações. É evidente que ele não utiliza o termo "niilismo" (e nem poderia, uma vez que, salvo engano, a palavra sequer existia); parece-nos o caso de perguntar, contudo, se não saímos da crítica espinosana à moral numa situação, num estado de espírito, muito próximo do niilismo oitocentista. Pensamos, por exemplo, naquele que termina a leitura da parte I da Ética e sobretudo de seu apêndice, indubitavelmente o mais duro dos textos espinosanos contra o finalismo e os valores. É do finalismo que se originam nossos valores, ou preconceitos, sobre "bem e mal, mérito e pecado, louvor e vitupério, ordem e confusão, beleza e feiúra, e outros desse gênero"; noções que nada dizem de real, mas "são tão-somente modos de imaginar", que "não indicam a natureza de coisa alguma, mas apenas a constituição da imaginação" (Espinosa, 1972, p.78 e 83). ${ }^{5}$ Ora, com que se depara o leitor? Ausência de sentido provocada pela desvalorização dos valores transcendentes e de modo geral a supressão de qualquer além.

A sensação de torpor que pode tomar o leitor do apêndice não é injustificada nem pura cessão a uma espécie de nostalgia do preconceito. Antes,

5 Para as nossas citações do apêndice servimo-nos de uma tradução inédita deste texto realizada pelo Grupo de estudos espinosanos da USP. 
é expressão sincera de um fato: a substância espinosana não nos oferece um mundo muito mais auspicioso que o mundo sem Deus. Tudo é necessário e determinado; não há livre arbítrio nem vontade livre (ou indeterminada ou que pudesse se indeterminar); não há causas finais; os seres reais são singulares e os universais não têm realidade; os valores (bem, mal, mérito, pecado etc.) são apenas noções que os homens se forjam e aplicam sobre as coisas, mas que nada exprimem de positivo, de real. Deparamos com um mundo de que é retirado qualquer traço humano, um mundo ermo, despido de humanidade, e que é e acontece a despeito de qualquer relação com o homem; nossas categorias e valores simplesmente nada exprimem de real e são sempre relativas: uma valoração das coisas que surge segundo o modo como cada coisa afeta cada homem segundo a constituição deste homem. Um mundo, enfim, em que igualmente faltam os fins e os porquês.

Ora, em Nietzsche, como já assinalado, a ultrapassagem do niilismo é possível prioritariamente pela criação de novos valores a partir de outras bases que a transcendência. Dado isso, nossa questão é: o mesmo se passa com Espinosa? Por extenso: o filósofo espinosista que promove uma análise dos valores e alcança um estágio que pode ser designado como de niilismo precisará, também ele, num segundo momento, criar ou forjar valores novos? E se sim, em que bases o fará? Enfim, após a crítica à moral, Espinosa chega a dar um passo semelhante ao de Nietzsche?

Cremos cabível uma resposta afirmativa. O filósofo espinosista terá como tarefa, uma vez feita a análise crítica dos preconceitos e da moral, a criação ou instituição (para usar um vocábulo mais próximo do universo espinosano) de novos valores que favoreçam a vida, isto é, favoreçam os encontros alegres e firmem-nos na busca da felicidade, que proporcionem o aumento de nossa potência. Mesmo que pouco importantes sob o prisma da realidade substancial, os valores terão um papel relevante a cumprir na constituição de um mundo humano, portanto no plano da realidade modal. É por essa via que nos parecem poder ser lidas algumas passagens espinosanas deveras curiosas em que, não obstante a tenaz denúncia do finalismo e da irrealidade de nossos valores (e sem arredar pé nisso), Espinosa procede a uma recuperação do que chama de "modelos" (exemplares), dos fins e dos valores. Um dos casos mais notórios é o da Ética IV, cujo prefácio - sem abrir mão de afirmar, frisemos ainda uma vez, a irrealidade dos valores e dos modelos universais - propõe a retomada das noções de fim, bom, mau que haviam sido expulsas do terreno filosófico um pouco atrás. Num curto trecho de texto, estão a crítica e o resgate do que é criticado.

Por que retomar tais noções após a destruição delas? Com que direito? É um passo necessário, isto é, sem o qual a economia do sistema não restaria ilesa? 
Deixando a Ética de lado para só retomá-la ao final, nossa intenção é investigar tais questões e justificar nossa resposta afirmativa a partir da análise de certas linhas mestras de um texto em que o filósofo, posto numa situação semelhante àquela da Ética I e IV, realiza um movimento que nos parece aproximar-se muito de uma criação de valores. Um texto significativamente belo, que relata nada mais nada menos que o início do filosofar espinosano, pondo a instituição de novos valores como uma ponte entre um passado de decepção e a promessa de uma vida melhor: o início do Tratado da emenda do intelecto.

\section{III}

Nossas facilidades (Erleichterungen) são aquilo por que temos de pagar mais duramente! E se queremos, depois, retornar à saúde, não nos resta nenhuma escolha: temos de nos carregar mais pesadamente (schwer) do que jamais estivemos carregados antes... (Nietzsche, 1987, v. 1, p.82.)

O Tratado da emenda do intelecto é uma obra de juventude que restou inacabada. Discute-se se se trata da primeira ou da segunda obra de Espinosa bem como o porquê de seu abandono. Os primeiros parágrafos, que se servem da primeira pessoa do singular, apresentam uma narrativa da conversão à filosofia e naturalmente do possível caráter autobiográfico do texto. Questão controversa pela qual não nos interessaremos aqui; para nós importa que se trace o percurso de um indivíduo à filosofia, tanto faz se Espinosa, outra pessoa, ou um personagem fictício.

O entrecho é bastante conhecido (algumas das páginas mais famosas do espinosismo) e, em certo sentido, previsível nos seus componentes: a decepção com a vida comum e o que ela propõe como felicidade; incertezas, a decisão de indagar por um bem verdadeiro, o filosofar, e assim por diante.

Depois que a experiência me ensinou que tudo que freqüentemente ocorre na vida comum é vão e fútil, como via que tudo que me provocava temor e que eu temia não tinha em si nada de bom nem de mau, a não ser na medida em que [meu] ânimo era comovido por isso, decidi (constitui) finalmente indagar se existia algo que fosse um bem verdadeiro, capaz de comunicar-se, e que, rejeitados todos os outros, fosse o único a afetar o ânimo; algo que, uma vez descoberto e adquirido, me desse para sempre (in aeternum) o gozo de contínua e suprema felicidade. $(\S 1)^{6}$

A partir desse primeiro parágrafo da obra podemos discernir três momentos estruturadores da narrativa; três etapas do percurso espinosano

6 Para as citações do Tratado da emenda do intelecto partimos sempre da tradução de Lívio Teixeira (Espinosa, 2004), modificando-a; aqui, o "meu" entre colchetes vem da tradução holandesa (cf. Espinosa, 1992). Por economia, na seqüência forneceremos apenas a paragrafação do Tratado, sem outras indicações. 
que leva da vida comum ao filosofar - o início da filosofia - que orientarão nossa análise.

1) "Depois que a experiência me ensinou...". Houve um ensinamento da experiência, tal ensinamento tem um "depois", logo deve ter um "antes". Qual o "antes", qual o ensinamento? Como se dão as condições de possibilidade do decidir-se pelo filosofar (isto é, indagar por um bem verdadeiro)?

2) "Decidi finalmente indagar...". Entre o ensino da experiência e a decisão há um tempo, um intervalo (do "depois" até o "finalmente"), que é o do decidir-se, um processo de decisão cuja condição de possibilidade é anterior.

3) Uma vez decidido a indagar por um bem verdadeiro, busca-se e determina-se tal bem; ele é descoberto, mesmo que ainda não tenha sido adquirido. É isso que permitirá o estabelecimento de um "fim" a determinar a via a ser seguida pelo filosofante.

O que permite a uma pessoa perguntar-se por um bem verdadeiro? Fundamentalmente a desconfiança de que os bens (e também os males) que lhe foram propostos sejam falsos ou pelo menos incertos. É exatamente isso o que a experiência permite a Espinosa ao ensinar-lhe a vanidade e futilidade de tudo, o vazio por trás das idéias de bem e mal; as coisas são boas e más apenas na medida em que nos afetam, já em si mesmas não são nem boas nem más; em resumo, "bem e mal não se dizem senão relativamente (respective)" (§12). A experiência ensina a suspeitar da escala de valores da "vida comum", faz caducarem tais valores e, assim, instala-nos desde o início para lá do bem e do mal.

Vejamos isso, a experiência no-lo ensina. Mas como a experiência pode chegar a abalar o sistema da vida comum em que estamos inseridos desde o nosso nascimento? Como chegar a suspeitar daquilo que sempre foi dado como verdade certa e inquestionável? Um rápido excurso pelo apêndice da primeira parte da Ética pode ser aqui bastante esclarecedor.

O apêndice deseja convocar os homens a um "exame da razão". Ele vem ao final da primeira parte da Ética, intitulada "De Deus", e busca desmontar alguns preconceitos que poderiam, no dizer do autor, impedir a boa compreensão das teses até então demonstradas. São vários os preconceitos, explica-nos Espinosa, mas todos eles redutíveis a um único, qual seja: "os homens comumente supõem as coisas naturais agirem, como eles próprios, em vista de um fim; mais ainda, dão por assentado que o próprio Deus dirige todas as coisas para algum fim certo: dizem, com efeito, que Deus fez tudo em vista do homem, e o homem, por sua vez, para que o cultuasse" (Espinosa, 1972, p.78).

Esse é o maior dentre os preconceitos humanos; um resultado, efeito de nossa imaginação. Conseqüentemente, fazendo jus à regra que manda 
"não caçoar, não lamentar, não detestar as ações humanas, mas entendêlas", a análise espinosana vai buscar compreender a gênese de tal preconceito e como ele transforma-se em superstição, sem nunca esquecer porém que mesmo um preconceito tem causas naturais e seu desenvolvimento deve explicar-se pela natureza humana. Ora, no espinosismo nada surge do nada, tudo tem causa, inclusive os preconceitos, e nessa medida eles são fatos positivos e que têm razões de ser como produtos da imaginação humana. Como afirma o filósofo, "todos são por natureza propensos a abraçar" o preconceito e o apêndice da Ética I será, pois, a investigação genética de um fato natural, a superstição.

Para apresentar a gênese do preconceito finalista, Espinosa parte de um fundamento que, no seu dizer, "deve ser admitido por todos"; um dado fundamental e universal que remete à condição primitiva dos homens: "Todos os homens nascem ignorantes das causas das coisas e todos têm o apetite de buscar o que lhes é útil, sendo disto conscientes." (ibidem) A partir disso o apêndice apresenta um percurso dedutivo cerrado, dando a ver como da situação originária dos homens chega-se ao preconceito e à superstição finalista. Este é um aspecto genial do texto. Assistimos à gênese de um sistema, uma estrutura ou construtura (Espinosa usa a palavra latina fabrica) que é também um sistema de vida dotado de valores, deveres e penas para os homens, explicações para o mundo, sua origem, seu funcionamento, seu fim.

Tudo isso ocorre com tal naturalidade e necessidade a partir da condição originária dos homens que nos fica a impressão de que nunca se poderia escapar a tal construtura; senão por um milagre, parece, homens preconceituosos, supersticiosos, lograriam dela furtar-se. Todos os homens, mencionemos mais uma vez a dura assertiva de Espinosa, "são por natureza propensos a abraçar o preconceito"; nesse sentido, surrupiar-se à superstiÇão seria um pouco como ir contra a natureza. Não obstante, em meio à análise Espinosa não deixa de sugerir que há sim possibilidade de escapar ao sistema da vida finalista. Isso é possível, por assim dizer, de dentro; não por intervenção da razão ou da matemática (cuja "norma de verdade", sabese, será louvada no mesmo apêndice), mas pela própria experiência de vida. Vejamos como isso aparece.

Estamos no âmago do finalismo. Quer dizer: concluiu-se que o mundo foi criado por Deus, que dispôs tudo em benefício dos homens a fim de que estes lhe prestassem honras, culto e obediência. Este é nosso dever e daí um código: quem louva e obedece ao dirigente da natureza é beneficiado, caso contrário, castigado; e quanto mais culto e obediência, mais benefícios, quanto menos culto e obediência, mais castigos. Os homens poderiam ser felizes seguindo tais prescrições, não fosse a desgraceira de que o mundo teima em contradizer as certezas propostas pelos finalismo. "Vê a que ponto chegaram as coisas", exclama Espinosa, os deuses e a natureza deli- 
ram. Qual delírio? A demonstração cotidiana de que os males estão por toda parte e atingem indistintamente os ímpios e os homens mais piedosos; igualmente, o fato de os bens serem angariados pelos ímpios e mais vis dentre os homens. Ou seja, todo dia a experiência sugere a incoerência do finalismo e de suas explicações para o mundo; todo dia, vai dizer nosso filósofo, a experiência protesta. E é tal protesto da experiência, da vida que pode produzir certo abalo na construtura, pois que pode ensejar a desconfiança quanto à validade do finalismo como sistema explicativo; um abalo, um chacoalhão que pode ser a faísca de uma liberação.

E embora a experiência todo dia protestasse e mostrasse com infinitos exemplos o cômodo e o incômodo sobrevirem igual e indistintamente aos pios e aos ímpios, nem por isso [os homens] largaram o arraigado preconceito: com efeito, foi-lhes mais fácil pôr esses acontecimentos entre as outras coisas incógnitas, cujo uso ignoravam, e assim manter seu estado presente e inato de ignorância, em vez de destruir toda essa construtura e excogitar uma nova. Donde darem por assentado que os juízos dos Deuses de longe ultrapassam a compreensão humana. (idem, p.79, grifos nossos)

Ora, é bem verdade que no apêndice, como se vê, o protesto da experiência não leva a lugar nenhum, ou melhor, leva ao aprofundamento da superstição com o aparecimento da idéia de que os fins divinos são insondáveis; Deus escreve certo por linhas tortas, se nós não lemos aí o belo plano que se realiza e só vemos incoerências, o problema é nosso. É isso que se passa. Porém, na contramão dessa saída "mais fácil" também lampeja uma possibilidade de liberação; algo mais difícil, sim, mas possível: "destruir toda essa construtura e excogitar uma nova". Note-se bem que a questão se põe entre o mais fácil e o mais difícil, não entre o possível e o impossível. É necessário fazer algo, mas o que se vai fazer é outra história.

Por que é necessário fazer algo?

Observemos que o protesto da experiência, o qual exige fazer algo, não é uma tese filosófica ou um despertar para a razão em meio ao preconceito; não, trata-se de um fato corriqueiro, cotidiano que produz uma desconfiança e mesmo uma desesperança quase triviais, bem humanas, a partir do interior do próprio preconceito. É o desespero do homem piedoso em face de uma tragédia repentina que lhe testa as convicções; é a descrença que vai se insinuando em uma pessoa cumpridora de seus deveres religiosos que, todavia, não tem suas promessas atendidas e às vezes experimenta uma vida de agruras e misérias. Os revezes da fortuna, não raramente, amolecem os ânimos mais tenazes, frustrando sem dó todas as expectativas: fazse tudo certo, e mesmo assim tudo dá errado. Duvidar, numa situação como essa, é absolutamente humano, e ninguém a isso escapa, inquebrantáveis que sejam os ânimos - "Deus meu, Deus meu, por que me abandonaste?"

Ora, quando nos sentimos abandonados e nossas certezas de vida se enfraquecem, algo precisa ser feito; no exemplo do apêndice, o que se faz é 
lançar mão da idéia de que os fins de Deus são insondáveis. Sendo o finalismo um sistema que explica o real, o que se tem de fazer é, por assim dizer, salvar os fenômenos, e por isso mostra-se necessária a clausula ad hoc da insondabilidade da vontade divina. A decepção, contudo, também pode nos levar noutra direção: a desconfiança relativamente ao código, aos valores que nos haviam sido dados; no limite, pode conduzir à destruição desse modo de vida finalista e - por que não? - à tentativa de forjar um novo modo de vida, indagando inclusive por um bem verdadeiro diferente daquele que se mostrou um engodo. Essa via não é trilhada no apêndice, mas ela surge inquestionavelmente como uma possibilidade.

Na seqüência do trecho de que tratamos, o apêndice nos afirma que, em razão do finalismo, a verdade poderia escapar para sempre aos homens não fosse a matemática ter trazido uma "outra norma de verdade"; em razão disso é comum aventar-se que o caminho da filosofia, no espinosismo, só se pode dar pela matemática. Contudo, é preciso não esquecer a continuação da frase: "e além da Matemática, também outras causas podem ser apontadas (que aqui é supérfluo enumerar), as quais puderam fazer que os homens abrissem os olhos para esses preconceitos comuns e se dirigissem ao verdadeiro conhecimento das coisas." (idem, p.79-80, grifos nossos) Talvez seja impossível conferir precisão a esse genérico "outras causas", mas não é esse tampouco o nosso propósito; desejamos apenas incluir aí, nessas "outras causas", a experiência que abre o Tratado da emenda do intelecto.

A experiência que ensina a vanidade e futilidade das coisas, no Tratado da emenda, é como a experiência que contradiz a "fábrica" ou o sistema da superstição, no apêndice. É difícil dizer que a experiência ensine uma norma de verdade (como a matemática), mas nos dois casos importa é que ela nos force a "abrir os olhos" para a incoerência e quiçá a falsidade do sistema em que estamos e no qual acreditamos; por um motivo muito simples: porque ele não dá conta, enquanto sistema, da própria experiência cotidiana, ou seja, a superstição falha, os ímpios são felizes, os piedosos são desgraçados, os "bens" levam à infelicidade, tudo é vão e fútil, etc. Esse descompasso perturba, faz duvidar, suspeitar e, no limite, sugere uma novidade, ao menos a possibilidade de se construir algo novo. Um abalo (mais ou menos violento) na estrutura a que nos encontramos presos (e a conseqüente incerteza quanto ao futuro no interior dela) acarreta um desprendimento paulatino com relação a tal estrutura, que no Tratado da emenda tem o nome de "vida comum". É desprendendo-se da vida comum e de seus grilhões que se pode pensar algo novo. No apêndice se falava em "excogitar uma nova construtura"; no início do Tratado da emenda encontramos, reiteradamente, a idéia de estabelecer um novo modo de vida, uma nova vida - a fórmula novum institutum se repete quatro vezes só nos onze primeiros parágrafos (uma no §3, duas no §6, uma no §11). Com efeito, a preocupação 
em instituir uma nova vida é a grande preocupação do início do filosofar no Tratado da emenda do intelecto.

Chegamos com isso ao segundo momento de nossa análise. Houve um abalo no sistema da vida comum; descobriu-se, pelas incoerências desse sistema, a sua convencionalidade: ele não nos propõe bens e males verdadeiros, em si, mas bens e males convencionais que só o são na medida em que nos afetam - desde, claro, que estejamos predispostos a isso. Esta brecha no sistema gera desconfiança e abre um campo para a mudança, para o novo. Abre uma possibilidade, mas só isso não basta; no apêndice isso também ocorre e não dá em nada. É que é preciso, além de desconfiar da vida que se leva, decidir construir algo novo, uma nova vida.

Decisão!? Não estávamos nós, com Espinosa, no terreno da pura determinação? Como agora conferir alguma relevância a tal noção que parece nos remeter ao livre arbítrio sempre dado, no espinosismo, como ilusório? Sim, é efetivamente uma questão de decisão. Embora seja este um dos pontos mais fascinantes do Tratado da emenda, não o trataremos por extenso; só algumas advertências que permitam a passagem para o ponto que nos interessa alcançar.

O tema da decisão no espinosismo é freqüentemente visto como problemático, já que se trata de um universo sem livre arbítrio, sem livre vontade, e sem tudo que sói à gente ver implicado na idéia de decidir-se. $\mathrm{Na}$ medida em que tudo isso falta ao espinosismo, parece a muitos difícil pensar a decisão nesta filosofia. Entretanto, se buscarmos compreender o decidir-se em Espinosa não por aquilo que lhe falta, mas não positivamente, podemos ir mais longe; no nosso caso particular, o decidir-se se caracteriza em primeiro lugar como ter de fazer algo. Há um abalo na construtura em que estamos, a do preconceito ou a da vida comum, somos coagidos a fazer algo, mas necessariamente o mesmo: podemos forjar-nos os fins insondáveis da divindade ou podemos - é o caso do Tratado da emenda - pôr-nos a pensar, a filosofar. As determinações talvez sejam as mesmas, as respostas todavia podem ser bem diferentes, ainda que não menos determinadas. É por isso, ponto a nosso ver fundamental, que uma decisão pode ser pensada, pode ser objeto de reflexão.

Quer dizer, a decisão efetivamente é um problema num universo sem livre arbítrio; mas justamente isto é capital: é só num mundo imune ao livre arbítrio que ela é um problema real que, por isso, pode ser pensada; é um processo determinado e passível de análise. Diferentemente do que ocorre quando se imagina um sujeito livre que pode decidir qualquer coisa para lá de todas as determinações, caso em que a decisão não é problema simplesmente porque assume os ares de mistério, um poço sem fundo; decidir, en- 
tão, decidir por qualquer coisa será sempre algo fácil. Uma rápida comparação entre o Discurso do método e o Tratado da emenda do intelecto põe isso a limpo no que respeita à decisão de filosofar. São duas narrativas do início do filosofar, muitas semelhanças, mas quantas diferenças! Descartes, é notável, parece ter nascido para a filosofia e para ser Descartes; é muito fácil ser Descartes, e por isso o filósofo da dúvida nunca duvida realmente, jamais, de sua vocação. Tudo se passa como se os célebres sonhos de 10 de novembro de 1619 o tivessem feito sair da cama no dia 11 pronto para mudar o orbe intelectual. Em se tratando de uma filosofia do livre arbítrio e em que a vontade livre é uma marca maior do homem (a marca do criador impressa na criatura), decidir algo não constitui grande problema. Há um parágrafo da primeira parte do Discurso do método que cremos emblemático: "fui nutrido nas letras...", começa o autor, arrolando todas as determinações de sua infância e juventude, para logo emendar: "... mudei de opinião" (Descartes, 1996, p.67). A mudança é rápida e fácil, o sujeito sobrepondo-se a toda e qualquer corrente impingida pela vida. Descartes não é um homem, é uma vocação que se realiza em plenitude. Por isso não há muito que discutir acerca de sua decisão de filosofar.

No Tratado da emenda, pelo contrário, encontramos todas as dúvidas do mundo, e as dúvidas de todo mundo; incertezas, idas e vindas, passos para trás, percalços na realização do que se estabelece como escopo. Dos primeiros parágrafos da obra ressalta um homem, não um herói da modernidade filosófica; um homem que quer pouco, mas que só com muita dificuldade consegue este pouco. Por isso, também, o início do Tratado é tão rico; desde que o livre arbítrio sai de cena, a decisão não se separa mais do decidir-se; ela é um processo e, sobretudo, processo passível de análise. É exatamente o que Espinosa nos propõe, uma análise de seu próprio decidirse pela filosofia, de um processo cujo tempo está bem marcado: não decidi pura e simplesmente, não há a imediatez do livre arbítrio - "decidi finalmente...". Não cabendo aqui descer aos meandros dessa auto-análise, limitamo-nos a corroborar tal ponto de vista com a indicação da presença de um metadiscurso que trabalha sobre hesitações e dúvidas reais, nunca dúvidas metódicas alavancadas por uma vontade soberana: ${ }^{7}$

§1: "depois que a experiência ensinou-me... e que vi... decidi finalmente..."

§2: "digo que decidi finalmente..."

7 Sobre a fórmula "dúvida real" aqui empregada em oposição a "dúvida metódica", ver a passagem do Tratado da emenda (\$77) sobre a idéia duvidosa e como eliminá-la: "Falo da verdadeira dúvida na mente (de vera dubitatione in mente), e não a que amiúde vemos ocorrer, a saber, quando uma pessoa diz, com palavras, que duvida, ainda que o ânimo não duvide; não cabe ao método emendar isto; cabe, antes, ao estudo da obstinação e de sua emenda." 
§7: "continuando a refletir, cheguei a perceber que, na medida em que pudesse deliberar profundamente..."

§10: "não foi sem razão que usei estas palavras na medida em que pudesse deliberar profundamente..."

A decisão é um problema a ser meditado sempre, e especialmente nos casos difíceis, sem cessão às facilidades. Decidir pelo mais fácil como os homens do apêndice é, perante o ter de fazer algo, decidir não fazer nada senão dar livre curso às coisas, no caso os preconceitos; é meramente deixar-se levar e seguir o curso da ignorância e servidão nativas. Por outro lado, decidir pelo mais difícil, transformar a si e à vida, é uma fonte de agruras, é um passo inclusive violento: violência contra a vida comum que levamos e pela qual somos levados, violência de algo que vem de fora e que nos obriga a pensar, refletir, meditar, deliberar; em certo sentido, a violência de ir contra a nossa situação natural, já que "por natureza" somos propensos a restar abraçados ao preconceito. Os termos de Espinosa no Tratado da emenda são fortes ao descrever a situação daquele que, decepcionado com os bens comuns, procura um outro; eles não nos permitem fazer pouco caso da dor acarretada pelo pensar no mais difícil:

Via-me, assim, rodear em extremo perigo (in summo versari periculo) e constrangido a procurar, com todas as minhas forças (summis viribus), um remédio, ainda que incerto; como um doente, atacado de fatal enfermidade, que antevê morte certa se não encontra um remédio, é constrangido a procurá-lo com todas as suas forças (summis viribus), mesmo que ele seja incerto, pois que nele está sua única esperança. (§7)

Todo o ser do indivíduo, todas as suas forças mobilizam-se nessa esperança. Esperança de alcançar algo banal, muito simples, mas cuja busca revela toda a vitalidade da narrativa. Não esperança de uma ciência segura, não de uma revolução filosófica, mas de "conservar o nosso ser" (§7), na metáfora médica, ou, no registro que nos é dado pela abertura do texto, esperança de chegar a gozar uma "suma alegria", esperança de ser feliz, em resumo.

A decisão pela alegria e pela busca da felicidade, a mais difícil das decisões, é como que o ato fundador do espinosismo. E é isso que nos encaminha para o terceiro momento da narrativa, ponto em que poderemos ver essa decisão, determinada, desdobrar-se numa criação de valores como bom e mau.

Uma suma alegria exige, antes de tudo, alegrar-se. Pergunta então inevitável: o que pode nos alegrar? Muitas coisas, indefinidas coisas, mas certamente não se incluirá aí algo que nos decepcione, isto é, algo que nos en- 
tristeça. Ora, o Tratado da emenda se abre pelo relato de uma decepção. Desde que nascemos, ou ao menos que nos damos por gente, a vida comum nos impinge a sua escala de valores: isso é um bem, aquilo é um mal; isso traz felicidade, aquilo traz desgraça. A vida comum liga-se inexoravelmente a um senso comum que mede e valora as coisas; e de nascença, sem a menor opção, estamos mergulhados nesse senso comum como estamos na ignorância das causas. No sistema da vida comum em questão no Tratado, os maiores bens são a honra, as riquezas e a sensualidade (libido); são eles que sustentam a promessa de alegria e felicidade. Cumprem-na, porém? Não. E é a decepção gerada por tal promessa incumprida, um engodo, que deflagra no início da obra um processo de questionamento (tudo é "vão e fútil") que perdura alguns parágrafos que se modulam conforme o ajuizamento do indagador vai se firmando: talvez tais bens não sejam tão certos, talvez sejam incertos, talvez, por fim, sejam com certeza incertos, isto é, certamente decepcionantes ou "males certos". 8

Tal percurso revalorativo, reiteremos, dura alguns parágrafos. O que no âmbito da narrativa espinosana deve ser entendido: a revaloração não se dá num átimo; há uma reflexão sobre a vida e o futuro, ponderação de prós e contras e uma verdadeira luta interior. Todos me dizem que isso é um bem e todos buscam isso; estou descontente, acho que algo não é um bem e vou atrás de outra coisa; mas e se eu estiver enganado (já me enganei) e todos certos? Reflexões desse teor atravessam o espírito de Espinosa no início do Tratado da emenda; tanto que ele não consegue nem mesmo dar livre execução às suas próprias deliberações. Embora "percebesse claramente", o narrador nos confidencia, quão decepcionantes são os bens que me são propostos, "não podia depor toda avareza, sensualidade e glória" (§10). Trata-se do lugar comum ovidiano, ${ }^{9}$ decerto, mas recoberto de um sentido todo especial advindo do contexto. A luta interna só terá termo quando se der uma completa reversão dos bens comuns e dos valores a eles vinculados, uma reorganização numa nova escala de valores, a qual permitirá ao filósofo pô-los no devido lugar, não para largá-los de vez, mas para deles usufruir sem decepção. Podemos ver em ação aqui a estratégia da moderação: dar medida, revalorar. O que vai mudar não são os bens ou as coisas, mas os valores conferidos a cada bem, a cada coisa e principalmente a nossa atitude perante os bens e as coisas. A intervenção da idéia de "bem verdadeiro" é que ope-

8 Tal análise que estima o valor dos bens comuns e do bem verdadeiro desenvolve-se entre os parágrafos 2-7 e encontram seus passos bem marcados: “... deixar o certo pelo incerto..." (§2); “... estaria deixando um bem incerto de sua natureza... por um outro incerto também, não todavia de sua natureza..." (§6); " ... estaria largando males certos por um bem certo..." (§7).

9 "Vejo o melhor e aprovo, sigo o pior" (Metamorfoses, VIII, 20), citado na Ética, IV, prop. 17, esc. 
rará isso; é por sua ação que se poderá determinar que "a busca das riquezas ou a sensualidade e a glória eram nocivos só enquanto procurados por si mesmos e não como meios para outras coisas"; e que, "em verdade, procurados só como meios terão modo (modum) e causarão muito pouco prejuízo; até, pelo contrário, conduzirão ao fim pelo qual são procurados." (\$11)

O surgimento do bem verdadeiro marca o reescalonamento de todos os valores e uma reorganização das coisas. E uma reorganização ou revaloração que assume um tom finalista; a noção de bem verdadeiro imporá moderação, modo, medida, estipulando às coisas um lugar de meio para atingir um fim determinado. Os parágrafos 12-13 constituem o núcleo dessa operação e vale a pena citá-los em sua inteireza, pois é a reflexão sobre o sentido da estratégia nele presente que constituirá o cerne de nossas conclusões.

Só em poucas palavras direi aqui o que entendo por bem verdadeiro e, igualmente, o que é o sumo bem. Para que se compreenda isso corretamente, deve-se notar que 'bem' e 'mal' só se dizem relativamente (respective), visto que, segundo diversos pontos de vista [ou diversas relações, secundum diversos respectus], uma mesma coisa pode ser dita boa ou má; assim também com o 'perfeito' e o 'imperfeito'. Efetivamente, coisa alguma, considerada só em sua natureza, pode ser dita perfeita ou imperfeita, principalmente depois que se chega a compreender que tudo o que acontece acontece segundo uma ordem eterna e segundo leis imutáveis da natureza. Como, porém, o pensamento humano, em sua fraqueza, não chega a alcançar aquela ordem e, entretanto (interim), concebe alguma natureza humana muito mais firme que a sua (aliquam humanam sua multo firmiorem), ${ }^{10}$ sem que nada pareça obstar a que ele venha a adquiri-la, o homem é levado a procurar os meios que o conduzem a essa perfeição; e assim a tudo o que pode ser meio para alcançá-la se chama 'bem verdadeiro'; e o 'sumo bem' é gozar, se possível com outros indivíduos, daquela natureza. Mostraremos, no lugar próprio, que aquela natureza é o conhecimento da união da mente com a Natureza inteira.

No imediato início do parágrafo seguinte, afirmará Espinosa: "eis então o fim ao qual tendo" (§14).

Como acatar, como entender esse movimento espinosano? Um passo desconcertante: o resgate do finalismo, renegado por todo o espinosismo e com particular força no apêndice da Ética I; a retomada do finalismo e de toda a sua miríade habitual de noções adjutórias: meio e fim, modelos, valores como bom, mau, perfeito, imperfeito. E tudo isso, note-se, num trecho

10 Ou, conforme a tradução de Lívio Teixeira, "superior"; recorde-se o campo de significação de firmus, a, um: firme, sólido, consistente, resistente, forte, vigoroso, saudável, constante, duradouro, invariável, poderoso. Ademais, observe-se que esta "alguma natureza humana muito mais firme que a sua" (aliquam humanam suâ multò firmiorem) é a confrontar com a passagem do apêndice em que os homens, diante de uma natureza que tudo lhes fornecia, "tiveram causa para crer em algum outro ser" (causam credendi habuerunt aliquem alium esse). 
que inicia justamente reafirmando a relatividade de bem e mal, ensinamento da experiência que é crucial para o início do questionamento filosófico. De pecado da juventude certamente não se trata, pois é o mesmíssimo passo, ou descompasso, presente no prefácio da Ética IV, no qual se parte de uma crítica à idéia de modelo, retoma-se o essencial das críticas do apêndice aos fins e aos valores, e se termina estabelecendo um "modelo de natureza humana" como fim e, com isso, resgatando as noções de bom e mau, perfeito e imperfeito.

Ora, tais movimentos paradoxais, em estreitos trechos, sem dúvida desconcertam; as viravoltas parecem estar mais para Pascal que para o pensar matemático. Busquemos compreender o que ocorre.

Há um resgate do finalismo, de algo que é dado por Espinosa como preconceito. Em particular, dá-se a retomada de valores que, sabemos, não contêm nenhuma realidade; bom, mau, perfeito, imperfeito e, levando a sério o metro espinosano (um modelo de natureza humana), todos os demais poderiam igualmente voltar à tona. Mas se trataria de uma simples retomada? Não, e este é o ponto capital. Após o ensinamento da experiência a retomada toma o feitio de uma manipulação consciente do finalismo, possível porque desde sua abertura o Tratado nos põe além do bem e o do mal em si.

O tornar-se filósofo, emendar-se e rumar para a liberdade não implica tanto parar de falar em bem e mal, meios e fins, mas forjar uma nova construtura, um novo instituto de vida que venha substituir a antiga construtura destruída. Destrói-se construindo, e tal construção também se aplica necessariamente aos valores e fins.

Ainda que as noções de bem, mal, etc. nada digam do real, sabemos que organizam o real e por conseguinte a vida das pessoas, que organizam o mundo humano. Isto corre, conforme o apêndice da Ética nos explica, necessariamente, determinadamente a partir de nossa condição nativa; os homens não escolhem forjarem-se valores e fins, fazem-no necessariamente. Ora, seria bem estranho então que a felicidade devesse passar pelo esquecimento de tudo isso que nos homens é necessário; nos termos do Tratado político espinosano, teríamos nesse caso menos uma ética que uma sátira (I, §1). O filósofo e sobretudo aquele que inicia na filosofia não pode esquecer o que é humano em seu novo modo de vida, ele precisa sim é fazer um uso consciente disso que é humano e necessariamente humano: uma manipulação criativa, se se quiser, e especialmente sem ilusões.

A descoberta fundamental do início do Tratado da emenda é a convencionalidade dos bens, dos valores que nos são propostos. Abre-se dessarte um horizonte sem bem nem mal nem fins; onde tudo acontece segundo uma 
"ordem eterna", segundo "leis imutáveis", as quais porém não alcançamos; trata-se apenas de um mundo que acontece. Pode-se ficar assim? Não. Após a descoberta da relatividade ou convencionalidade dos valores e dos fins, será preciso restabelecer o bem, o mal, os fins; eles serão, decerto, tão convencionais quanto os anteriores, ou seja, tampouco vão remeter a algo de real; mas podem tornar-se instrumentos no caminho da felicidade. Por pouco que nos descolemos do sistema da vida comum e descubramos sua artificialidade, de imediato abre-se nós a possibilidade de uma reorganização da vida. Por que não propor uma nova organização? E como todo o problema do Tratado desde o início é a felicidade ("o gozo de contínua e suprema felicidade"), por que não propor uma reorganização das coisas e da vida que favoreça ao máximo nosso caminho para a felicidade? Uma reorganização dos valores que favoreça os encontros alegres e o afastamento das tristezas?

É bem disso que se trata: pôr ordem nos afetos. É o que executam o modelo de natureza humana "mais firme" e o "bem verdadeiro" dele decorrente assim que surgem na narrativa do Tratado da emenda: tolhem as dúvidas, dão um novo conteúdo aos valores, revaloram as coisas, estabelecem meios e fins; numa palavra: ordenam. E por isso mesmo falamos de um verdadeiro bem. A verdade do verdadeiro bem não está em corresponder a nada no real, mas em seu poder ordenador e no fato de não ser decepcionante; é a verdade de uma eficácia no alegrar, e efetivamente o Espinosa que inicia na filosofia alegra-se com a passagem de uma vida comum em que predominam as tristezas a uma nova vida em que podem predominar as alegrias. O bem verdadeiro é um metro que deriva de um fim, um modelo de natureza humana que nos impomos. O metro não é o da verdade das coisas mas do poder de produzir alegria. Os termos do texto não nos deixam enganar; nenhuma ilusão de que o bem verdadeiro seja algo real, uma coisa. Pouco antes de apresentá-lo, o texto reforça que bom e mau só se dizem "relativamente" (respective) e que as coisas podem ser boas ou más segundo vários pontos de vista (secundum diversos respectus); não se nega esta relatividade nem mesmo no momento de estabelecer um princípio e uma nova ordem: precisamente, o homem forja "alguma natureza humana muito mais firme que a sua" (sua multo firmiorem), ou seja, com relação, com respeito a sua natureza. Nada se fala em sentido absoluto ou acerca das coisas em si. O bem verdadeiro será, propriamente falando, uma relação: "tudo o que pode ser meio para alcançar" aquela natureza mais firme "chama-se bem verdadeiro"; e podemos acrescentar, ainda que Espinosa não o faça: mal verdadeiro será o que atrapalha o nosso avanço rumo àquela natureza humana. Bem e mal são aqui lugares, relações, espaços nessa nova ordem que o iniciante se impõe. Nova ordem que, cumpre repetir, poderá organizar os afetos de modo que o iniciante possa alegrar-se ao moderar os afetos. Não é à toa que Espinosa diga que, segundo essa nova relação, mesmo aqueles bens decepcionantes 
como honras e riquezas possam vir a ser procurados sem dano; com efeito, "procurados só como meios terão modo (modum)", quer dizer, terão medida, estarão dentro de uma ordem que os medirá e avaliará, que os moderará, e não serão mais buscados como "fins" em si mesmos (§11).

Tudo isso, observe-se, é feito segundo um esquema finalista; numa manipulação desse esquema que sequer chega a invocar qualquer princípio racional. Pelo contrário, cumpre insistir que, quanto à "ordem eterna" e às "leis imutáveis da natureza" mencionadas no mesmo parágrafo que nos apresenta o verdadeiro bem, Espinosa é incisivo ao afirmar que não chegamos a alcançar tal ordem. Ora, podem-se tecer várias dúvidas se, no final das contas, o ganho não é bem magro. Elas não se sustentam, contudo, se soubermos apreciar o ocorrido. Pode parecer pouco, pode parecer que andamos, andamos e não saímos do lugar; mas a impressão é falsa. O maior dos acontecimentos - o da liberação pelo filosofar - começou a despontar, movido pela mais difícil das decisões - ser livre.

Continuamos com fins, com valores, com tudo isso; mas houve uma mudança na essência desses fins e valores. Antes eles eram simplesmente dados a nós; aconteciam simplesmente, ocorriam sobre nós e nos aprisionavam; agora nós os forjamos, nós os fabricamos, reconhecemos a artificialidade deles e desta nos servimos sem estar a ela aferrados. Antes servíamos às coisas, agora as coisas nos servem. O que mudou, qual o resultado da passagem? A liberdade. Um lampejo inicial, quase imperceptível, mas já um primeiro passo: não somos servos, tornamo-nos agentes (ao menos nisso); não somos apenas determinados por tudo e a tudo, mas com relação a algo nós nos determinamos; com relação a algumas coisas, a alguns aspectos de nossa vida, podemos agora dizer que somos autônomos, ou seja, que nos regramos por nós mesmos, dando modo e medida a nós e a nossa vida. E isto nos alegra. É preciso levar aqui muito a sério a idéia, presente na quinta parte da Ética, de um poder de ordenar as afecções, potestas ordinandi, que somos capazes de exercer quando não estamos por elas dominados, ${ }^{11}$ portanto, enquanto, em alguma medida, somos livres. A liberdade aqui se vincula ao que já dissemos sobre a decisão: o mais difícil é decidir fazer algo, algo novo, em vez de só deixar as coisas seguirem o seu curso, que nos arrasta para lá e para cá. Fazer algo é ser livre; uma liberdade que se exprime como o exercício de um poder ou potência de determinar em vez de apenas padecer, especialmente exprime-se como autodeterminação.

11 "Durante o tempo em que nós não somos dominados pelas afecções que são contrárias à nossa natureza, durante esse mesmo tempo nós temos o poder de ordenar e encadear as afecções do corpo segundo uma ordem para o intelecto." (Ética, V, prop. 10) 
No caso do início do Tratado da emenda, como percebemos lendo-o junto do apêndice, logramos fazê-lo usando dos mecanismos do preconceito a nosso favor. É uma mudança de perspectiva, é verdade, mas não é somente uma mudança de perspectiva; é isto mesmo que determina toda a transformação que nos põe na via da felicidade; transformação inseparável de uma liberdade de forjar-se modelos, fins, valores. Inverte-se destarte a direção das determinações e de paciente tornamo-nos, em algo, agente; antes só éramos determinados pelo que vinha de fora, agora há uma determinação em sentido contrário, de dentro para fora, que se deverá consumar numa vida nova, um novum institutum, para lembrar a fórmula utilizada ao início do Tratado não menos que quatro vezes.

\section{IV}

Finalmente, retornemos a nossa indagação inicial: criam-se valores no espinosismo? Parece-nos justa uma resposta afirmativa. Visto que nada é bom ou mau em si, que a natureza não contém fins nem modelos de coisa alguma, conferir algum sentido, qualquer sentido, a tais noções será criar, instituir, repor em uso convenções, modos de pensar humanos que são valores. Uma leviandade ou o equivalente, na filosofia, a uma licença poética? De forma alguma, pois não só se criam valores como é necessário criar valores. O mundo humano produz valores e sem estes não pode assumir o estatuto de mundo humano; os homens formam-se valores naturalmente, determinadamente a partir de sua condição originária; o problema, nesse caso, não serão os valores, mas quais valores e qual o escopo deles; em certo sentido, o valor desses valores. Não há obra espinosana que deixe transparecer ilusões sobre valores absolutos; pelo contrário, afirma-se com ênfase que todo valor é relativo. Mas relativizar não implicará ficar sem quaisquer valores. Relativizar é, em primeiro lugar, perder ilusões, conhecer o que é um valor e qual seu lugar; segundo, autonomamente, forjar-se valores ou resgatar outros renovando-os. No fundo, é assim que se pode ler e interpretar o curioso movimento espinosano do proêmio do Tratado da emenda do intelecto.

Deleuze afirmava que Espinosa possuía uma "filosofia da vida", e assim a definia: "ela consiste em denunciar tudo o que nos separa da vida, todos esses valores transcendentes que se orientam contra a vida, vinculados às condições e às ilusões da nossa consciência." (Deleuze, 2002, p.32) Correto, mas cumpre igualmente salientar que a esse trabalho crítico, que nos dá ciência de nossas condições e das ilusões de nossa consciência, é necessário seguir-se um trabalho de criação de valores e, portanto, de uma nova vida, ou novas vidas. O que será criar valores senão testar outras formas de 
vida, novas maneiras (de preferência alegres) de existir? Parece ser esta toda a preocupação do iniciante em filosofia no Tratado da emenda; e queremos insistir que não devemos enxergar aí um pecado de juventude: o filósofo maduro da quarta parte da Ética não fará coisa muito diferente, ainda que lá o movimento nos conduza por caminhos bem mais complexos que os do texto juvenil. ${ }^{12}$

Dessa forma, a questão toda de nosso texto pode esquadrinhar-se assim: já que os valores são necessários, tratemos nós de forjá-los em vista da alegria e do benefício à vida. Poder fazê-lo talvez seja o mais difícil; mas precisamos fazê-lo. Se não o fizermos, se nos restringirmos ao mais fácil, o preconceito, a tristeza, a superstição e o seu lugar-tenente - o teólogo - o farão por nós. O resultado... Bem, o resultado será aquele que conhecemos há séculos e contra o qual tanto Espinosa quanto Nietzsche sempre combateram.

SANTIAGO, Homero. The spinozian philosopher should create values? Trans/Form/ Ação, (São Paulo), v.30(1), 2007, p.127-149.

- ABSTRACT: Spinoza and Nietzsche have promoted a critical analysis of the current morality; both rose to discover the untruth of the conception of transcendent values. For Nietzsche, such discovery leads him to determine the creation of values as an imperative task of the new philosophers. Could the same be applied to Spinoza? In the Spinozism, could we not find something similar to a need for creation of values? We have tried to answer these questions mainly analyzing the beginning of On the improvement of the understanding.

- KEYWORDS: Spinoza, Nietzsche, values, morality, good and evil.

\section{Referências bibliográficas}

DELEUZE, G. Espinosa. Filosofia prática. Trad. de Daniel Lins e Fabien Pascal Lins. São Paulo: Escuta, 2002.

DELEUZE, G. Spinoza et le problème de l'expression. Paris: Minuit, 1968.

12 A este respeito, cabe observar que não desconhecemos as dificuldades que a aproximação entre Espinosa e Nietzsche impõe no momento em que passamos do plano do indivíduo (por onde inicia o Tratado da emenda) ao plano social. Com efeito, o iniciante do Tratado, após definir o "sumo bem", é bem claro quanto a isso: "faz parte de minha felicidade o esforçar-me para que muitos outros pensem como eu e que seu intelecto e seu desejo coincidam com o meu intelecto e o meu desejo [...]; e depois formar a sociedade que é desejável para que o maior número possível chegue fácil e seguramente àquele objetivo" (§14). Ora, esse aspecto social, se podemos assim dizer, da conversão filosófica espinosana (e que se revelará com toda força nas obras de maturidade) é reconhecidamente estranho à filosofia nietzschiana. 
DESCARTES, R. Obras. Trad. de J. Guinsburg e Bento Prado Júnior. São Paulo: Nova Cultural, 1996. (Col. Os Pensadores)

ESPINOSA, B. de. Ethica. In: Opera. Edição de Carl Gebhardt. Heidelbergue: Carl Winters Universitætbuchhandlung, 1972, v.2.

. Traité de la réforme de l'entendement. Trad. de Bernard Rousset. Paris, Vrin, 1992.

. Tratado da emenda do intelecto. Trad. de Lívio Teixeira. São Paulo: Martins Fontes, 2004.

LIVERI, G. T., Nietzsche e Spinoza. Ricostruzione filosofico-storica di um incontro impossibile. Roma: Armando, 2003.

NIETZSCHE, F. A gaia ciência. Trad. de Paulo César de Souza. São Paulo: Companhia das Letras, 2001.

Além do bem e do mal. Trad. de Paulo César de Souza. São Paulo: Companhia das Letras, 1992.

An Franz Overbeck (Postkarte) [Sils-Maria, 30. Juli 1881]. In: Sämtliche Briefe. Berlim, Nova Iorque: Walter de Gruyter, 1986, v. 6.

Assim falou Zaratustra. Trad. de Mário da Silva. São Paulo: Civilização Brasileira, 2005a.

Genealogia da moral. Trad. de Paulo César de Souza, São Paulo: Companhia das Letras, 1998.

Obras incompletas. Seleção de textos de Gérard Lebrun, trad. de Rubens Rodrigues Torres Filho. São Paulo: Nova Cultural, 1987. (Col. Os Pensadores)

. Sabedoria para depois de amanhã. Seleção de fragmentos póstumos por Heinz Friedrich, trad. de Karina Jannini. São Paulo: Martins Fontes, 2005b.

Werke. Kritische Studienausgabe. Edição de Giorgio Colli e Mazzino Montinari. Berlim, Nova Iorque: Walter de Gruyter, 1999. 